\title{
PRINSIP-PRINSIP PEMBELAJARAN BAHASA INDONESIA
}

\author{
Oleh: Ibrahim*
}

\begin{abstract}
Some people argue that the teaching of Indonesian has not been satisfactory in terms of quality and its relevance to students need. In fact, the ability of students to express their idea logically is still considered poor. This is one of issues which needs solution. With regard to this issue, a number of factors should be put under considerations including the principle of curriculum, syllabi, approach and method, teaching process, and the principle of teaching Indonesian.
\end{abstract}

KEYWORDS: Pembelajaran, keterampilan berbahasa, metode

PEMBELAJARAN bahasa Indonesia dewasa ini tampaknya masih menjadi isu aktual dalam berbagai forum ilmiah, terutama terkait dengan fakta bahwa pembelajaran bahasa Indonesia di berbagai jenjang pendidikan belum berjalan dengan baik sebagaimana yang diharapkan. Hal ini dilatari oleh hasil ujian nasional pada tahun 2007 yang menunjukkan bahwa bidang studi yang tertinggi tingkat ketidaklulusannya dari sejumlah bidang studi yang diujikan dalam ujian nasional adalah bidang studi bahasa Indonesia. Hal ini sejalan dengan sinyalemen negatif yang mengemuka dalam forum-forum ilmiah bahwa pembelajaran bahasa Indonesia pada prinsipnya belum memadai, baik dari segi kualitas, kuantitas, maupun relevansinya dengan kebutuhan. Proses pembelajaran bahasa Indonesia berjalan seadanya dan monoton sehingga kegiatan pembelajaran terpasung dalam suasana yang kaku. Dengan begitu, pebelajar kurang mampu mengungkapkan gagasan, perasaan, dan pengalamannya secara logis, runtut, dan mudah dipahami oleh pembaca. ${ }^{1}$ Hal ini merupakan problematika mendasar dalam pembelajaran bahasa Indonesia yang perlu direspon dan diupayakan solusinya dengan mengedapankan prinsipprinsip pembelajaran bahasa Indonesia.

Ada sejumlah prinsip yang bertalian dengan pembelajaran bahasa Indonesia, baik langsung maupun tidak langsung. Sejumlah prinsip

*Magister Pendidikan dalam bidang bahasa Indonesia ini adalah lulusan Program Pascasarjana Universitas Negeri Makassar tahun 2002. Selain sebagai dosen tetap pada Fakultas Ushuluddin dan Filsafat UIN Alauddin, ia juga menjadi sekretaris Lembaga Pengabdian Masyarakat UIN Alauddin Makassar. 
tersebut antara lain meliputi: (1) prinsip kurikulum, (2) prinsip silabus, (3) pengembangan keterampilan berbahasa dalam berbagai tindak komunikasi yang bermakna bagi pebelajar, (4) penerapan metode dan pendekatan yang dapat menjalin interaksi multiarah secara komunikatif dalam kegiatan pembelajaran, (5) penerapan segmen-segmen kebahasaan dalam tataran bahasa yang baik dan benar; "baik" dalam arti sesuai konteks komunikasi, dan "benar" dalam arti sesuai kaidah-kaidah kebahasaan, dan (6) penerapan berbagai metode dan pendekatan yang dapat menjalin interaksi multiarah secara dinamis antara pengajar dengan pebelajar, antara pebelajar dengan pebelajar, antara pebelajar dengan literatur atau bahan ajar. Hal ini dimaksudkan agar pebelajar aktif belajar untuk memperoleh kemahiran berbahasa Indonesia melalui kegiatan bernalar secara runtut dan logis dengan menuturkan hasil pemikirannya atau pengalamannya.

\section{ANALISIS TERHADAP PRINSIP-PRINSIP PEMBELAJARAN BAHASA INDONESIA}

\section{Prinsip Kurikulum}

Prinsip dasar kurikulum adalah "kesatuan dalam kebijakan dan keberagaman dalam pelaksanaan." Prinsip kesatuan dalam kebijakan, yaitu dalam mencapai tujuan pendidikan perlu ditetapkan standar kompetensi yang harus dicapai oleh peserta didik sebagaimana orientasi kurikulum berbasis kompetensi (KBK), demikian pula KTSP, khususnya yang terkait dengan tujuan pembelajaran bahasa Indonesia, yakni pembentukan pengetahuan, wawasan, keterampilan, dan sikap dalam berbahasa Indonesia. ${ }^{2}$ Sedangkan prinsip "keberagaman dalam pelaksanaan", yaitu dalam penyelenggaraan pendidikan yang meliputi perencanaan, pelaksanaan kegiatan pembelajaran, penilaian, dan pengelolaannya mengakomodasi perbedaanperbedaan yang berkaitan dengan kesiapan potensi akademik, minat, lingkungan, budaya, dan sumber daya daerah dengan karakteristik satuan pendidikan. ${ }^{3}$

Secara umum prinsip kurikulum merujuk kepada tujuan pendidikan nasional yang telah diundangkan dalam Undang-undang Nomor: 20 Tahun 2003 tentang Sistem Pendidikan Nasional Bab II Pasal 3 yang mengatakan bahwa: "Pendidikan nasional mengembangkan kemampuan dan membentuk watak serta peradaban bangsa yang bermartabat dalam rangka mencerdaskan kehidupan bangsa, bertujuan untuk mengembangkan potensi peserta didik agar menjadi manusia yang beriman dan bertakwa kepada Tuhan Yang Maha Esa, berakhlak mulia, sehat, berilmu, cakap, kreatif, mandiri, dan menjadi warga negara yang demokratis, serta 
bertanggung jawab". 4 Dengan demikian, jabaran kurikulum dalam berbagai segmen keilmuan hendaknya mempertimbangkan beberapa prinsip berikut ini:

- Keimanan, nilai-nilai, dan budi pekerti luhur yang perlu digali, dipahami, dan diamalkan oleh peserta didik.

- Penguatan integritas nasional yang dicapai melalui pendidikan yang memberikan pemahaman tentang masyarakat Indonesia yang majemuk dan kemajuan peradaban bangsa Indonesia dalam tatanan peradaban dunia yang multikultur dan multibahasa.

- Keseimbangan berbagai bentuk pengamalan belajar peserta didik yang meliputi etika, logika, estetika, dan kinestetika.

- Penyediaan tempat yang memberdayakan semua peserta didik untuk memperoleh pengetahuan, keterampilan, dan sikap sangat diutamakan.

- Kemampuan berpikir dan belajar dengan mengakses, memilih, dan menilai pengetahun untuk mengatasi situasi yang cepat berubah dan penuh ketidakpastian merupakan kompetensi penting dalam menyikapi perkembangan ilmu pengetahuan dan teknologi.

- Kurikulum perlu memuat unsur keterampilan atau kecakapan hidup agar peserta didik memiliki keterampilan, sikap, dan perilaku adaptif, kooperatif, dan kompetitif dalam menghadapi tantangan dan tuntutan kehidupan sehari-hari secara efektif.

- Pendidikan berlanjut sepanjang hidup manusia untuk mengembangkan, menambah kesadaran, dan selalu belajar memahami dunia yang selalu berubah dalam berbagai bidang. Kemampuan belajar sepanjang hayat dapat dilakukan melalui pendidikan formal dan nonformal, serta pendidikan alternatif yang diselenggarakan baik oleh pemerintah maupun oleh masyarakat.

- Upaya memandirikan peserta didik untuk belajar, bekerja sama, dan menilai diri sendiri sangat perlu diutamakan agar peserta didik mampu membangun pemahaman dan pengetahuannya. Penilaian berkelanjutan dan komprehensif menjadi sangat penting dalam rangka pencapaian upaya tersebut.

- Pendekatan yang digunakan dalam mengorganisasikan pengalaman belajar berfokus pada kebutuhan peserta didik yang bervariasi dengan mengintegrasikan berbagai disiplin ilmu. Keberhasilan pencapaian pengalaman belajar menuntut kemitraan dan tanggung jawab bersama dari peserta didik, pendidik, lembaga pendidikan, orangtua, dunia usaha dan industri, serta masyarakat. ${ }^{5}$

Prinsip-prinsip kurikulum di atas, pada dasarnya mensinergikan tiga potensi pada diri manusia, yaitu potensi keberimanan, keberilmuan, dan 
kekaryaan. Dengan demikian, prinsip-prinsip umum kurikulum tersebut di atas merupakan penyatalaksanaan dari firman Allah yang pertama-tama diturunkan khususnya ayat pertama, yang memerintahkan manusia untuk memperkaya diri dengan ilmu pengetahuan ( $\mathbf{f}$ ), mengembangkan

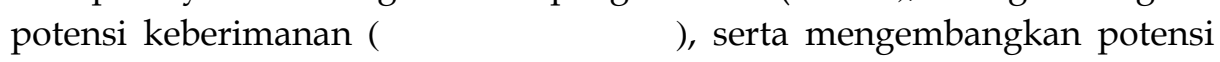

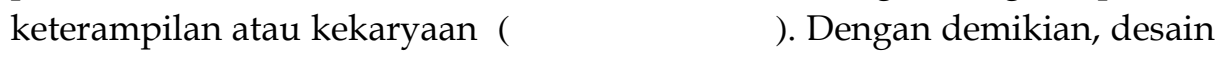
keilmuan dalam Islam mengarahkan untuk mengembangkan tiga potensi yang terdapat dalam diri manusia, yaitu memperkaya akal dengan ilmu pengetahuan, mengisi hati dengan nilai-nilai keberimanan, serta membekali pancaindra dengan berbagai bentuk keterampilan hidup.

Ketiga potensi di atas harus dibina secara paralel dan berimbang untuk mencapai keseimbangan hidup secara sehat. Jika salah satu potensi terabaikan, maka akan melahirkan kepincangan hidup. Misalnya, akal diperkaya dengan berbagai ilmu pengetahuan, tetapi hati tidak diisi dengan nilai-nilai keimanan, maka akan melahirkan ilmuwan yang berwawasan luas, tetapi krisis ketenangan. Jika hati diperkaya dengan nilai-nilai spiritual, tetapi akal tidak dibekalai dengan ilmu pengetahuan, maka akan melahirkan agamawan yang fanatik, tetapi kaku. Selanjutnya, apabila akal diperkaya dengan ilmu pengetahuan, hati dipenuhi dengan nilai-nilai spiritual, tetapi nafsu dan pancaindra selaku potensi kekaryaan tidak dibekali dengan kecakapan dan keterampilan berkarya, maka akan merajalela kemiskinan di tengah-tengah kehidupan. Oleh karena itu, kurikulum hendaknya meliputi tiga rana/potensi pada diri peserta didik.

Kurikulum merupakan acuan dasar pembentukan dan penjaminan tercapainya kompetensi lulusan. Oleh karena itu, kurikulum disusun berdasarkan hasil kajian mendalam tentang hakikat keilmuan suatu bidang studi yang dipadukan dengan perkembangan ilmu pengetahuan dan teknologi, sehingga kurikulum senantiasa berkembang sesuai dengan kemajuan dan perkembangan ilmu pengetahuan.

\section{Prinsip Silabus}

Ada beberapa prinsip yang perlu dipertimbangkan dalam penyusunan silabus, antara lain karakteristik peserta didik, tujuan atau kompetensi yang akan dikembangkan (dibentuk), hakikat materi, sumber bahan ajar, media pembelajaran, fasilitas yang tersedia, dan waktu yang dibutuhkan untuk mencapai indikator kompetensi yang telah ditetapkan.

Bentuk silabus hendaknya bersifat dinamis karena banyaknya variabel yang mempengaruhi model perkembangan silabus. Artinya, suatu silabus dapat dilaksanakan dengan baik pada kelompok tertentu, tetapi belum tentu dapat diterapkan pada kelompok yang lain. Suatu model 
silabus dapat diterapkan oleh tenaga pengajar tertentu, tetapi belum tentu dapat diterapkan dengan baik oleh tenaga pengajar yang lain. Menurut Sudjatmiko dan Lili Nurlaili, pada prinsipnya silabus atau model pembelajaran bahasa Indonesia yang standar adalah yang dapat mengembangkan empat keterampilan berbahasa bagi peserta didik dan meliputi komponenkomponen pembelajaran bahasa. Oleh karena itu, setiap tenaga pengajar bahasa Indonesia diharapkan dapat mengembangkan silabus sesuai dengan krakteristik pribadi, baik pribadi tenaga pengajar maupun karakteristik peserta didik, serta kondisi lingkungan. Dengan begitu, sewaktuwaktu silabus dapat dikaji ulang oleh para pakar yang terdiri atas pakar kurikulum, pakar dalam bidang keilmuan tersebut, pakar dalam bidang pendekatan/metode, pakar penilaian, serta pelaku pendidikan yang sudah berpengalaman di bidangnya. 6

Bentuk rencana sajian pelajaran bahasa Indonesia tampak bermacammacam, tergantung pada sistem penyajiannya. Bila menggunakan sistem belajar jarak jauh, rencana sajiannya cenderung menggunakan modul, paket belajar atau pengajaran berpogram (melalui radio atau televisi dan atau internet). Sementara itu, bila sistem belajar yang digunakan adalah tatap muka secara klasikal, rencana sajian yang lebih tepat adalah program satuan pelajaran yang disusun secara runtut dalam silabus.

Silabus merupakan perencanaan pembelajaran yang dijadikan acuan oleh tenaga pengajar untuk melaksanakan kegiatan pembelajaran sehingga pebelajar dapat mencapai kompetensi yang diharapkan. Oleh karena itu, silabus harus disusun secara sistematis dan berisikan berbagai komponen yang runtut dan dapat memandu tenaga pengajar dalam mengelola pembelajaran. Komponen-komponen tersebut adalah:

1. Kompetensi

Kompetensi merupakan komponen utama silabus dan berfungsi untuk mengingatkan tenaga pengajar seberapa jauh tuntutan terget kompetensi yang harus dicapai oleh pebelajar dalam hasil belajarnya.

2. Indikator

Setiap kompetensi memiliki seperangkat indikator yang dapat diukur dengan menggunakan berbagai teknik dan alat penilaian.

3. Materi

Materi pembelajaran yang dipilih untuk mencapai kompetensi adalah materi pembelajaran yang bermakna. Hal ini dimaksudkan agar pebelajar terhindar dari materi-materi yang tidak menunjang pencapaian kompetensi. Kriteria pemilihan materi ajar tersebut disesuaikan dengan perkembangan dan tingkat kemampuan pebelajar, di samping harus bersifat aktual, esensial, atau penting untuk dipelajari, bermanfaat, dan dapat menambah khasanah keilmuan peserta didik. ${ }^{7}$ 
4. Langkah-langkah pembelajaran

Ada beberapa tahap yang harus ditempuh dalam menyusun program pembelajaran bahasa, antara lain:

$\Rightarrow$ Menganalisis kebutuhan, kompetensi, indikator kompetensi, dan perioritas

$\Rightarrow$ Menganalisis sumber daya, hambatan, dan sistem penyajian

$\Rightarrow$ Menetapkan ruang lingkup dan urutan pembahasan serta sistem penyajian

$\Rightarrow$ Menetapkan struktur kurikulum (materi) dan urut-urutannya

$\Rightarrow$ Menganalisis tujuan kurikulum

$\Rightarrow$ Menetapkan tujuan performansi

$\Rightarrow$ Menyiapkan rencana bidang studi (silabus)

$\Rightarrow$ Memilih dan mengembangkan materi dan media

$\Rightarrow$ Menelusuri performansi

$\Rightarrow$ Melakukan persiapan

$\Rightarrow$ Mengadakan evaluasi formatif

$\Rightarrow$ Mengadakan tes lapangan dan revisi

$\Rightarrow$ Mengadakan Evaluasi sumatif.

$\Rightarrow$ Menetapkan berlakunya dan mensosialisasikannya. ${ }^{8}$

Pada bagian lain Sudjatmiko mengemukakan bahwa rumusan pengalaman belajar hendaknya menetapkan secara tepat metode dan strategi pembelajaran yang digunakan sehingga dapat:

$\Rightarrow$ Memberi peluang bagi pebelajar untuk mencari, mengolah, dan menemukan sendiri pengetahuan di bawa bimbingan tenaga pengajar.

$\Rightarrow$ Mendorong pebelajar secara aktif melalui observasi, penyelidikan, eksperimen, diskusi, pemecahan masalah, simulasi, wawancara dengan nara sumber, melaporkan atau mengkomunkasikan gagasan sesuai muatan materi.

$\Rightarrow$ Mengkombinasikan antara kegiatan belajar perseorangan, pasangan, kelompok, dan klasikal.

$\Rightarrow$ Memperhatikan perbedaan individual pebelajar seperti bakat, kemampuan, minat, latar belakang keluarga, sosial-ekonomi, dan budaya, serta masalah khusus yang dihadapi pebelajar yang bersangkutan.

5. Media pembelajaran

Media pembelajaran adalah semua bentuk perantara yang dipakai dalam kegiatan pembelajaran sebagai penyebar gagasan dan informasi. M. C. Luhan, seorang ahli komunikasi, dalam Subana dan Sunarti mengemukakan bahwa media adalah semua saluran pesan yang dapat digunakan sebagai sarana komunikasi dari seseorang kepada orang 
lain. ${ }^{9}$ Dengan demikian, media adalah semua bentuk perantara untuk menyebar, membawa, atau menyampaikan sesuatu pesan, gagasan (ide) kepada penerima.

Jadi, pada prinsipnya media pembelajaran bermanfaat untuk membangkitkan motivasi belajar, memberikan stimulus bagi kemauan belajar, menarik minat pebelajar, menumbuhkan pengertian, memberikan data yang kuat/terpercaya, memudahkan penafsiran data, dan memadatkan informasi. ${ }^{10}$

6. Penilaian

Setiap penilaian perlu menetapkan aspek yang diukur (kognitif, afektif, atau psikomotorik) secara proporsional serta menggunakan berbagai teknik penilaian (tertulis, penampilan, atau performansi) yang dapat mendeskripsikan secara jelas tugas yang harus diselesaikan sekaligus dapat mengukur indikator keberhasilan untuk mengetahui hasil belajar. ${ }^{11}$

Sesungguhnya, penilaian itu tidak hanya terbatas pada kemajuan dari hasil belajar, tetapi juga pada program dan proses pembelajaran. Dalam pengertian sempit, penilaian memang merupakan langkah terakhir dari proses pembelajaran yang dilaksanakan. Berkaitan dengan pengertian sempit ini, penilaian dapat dibedakan menjadi penilaian formatif, sumatif, dan EBTA/Ebtanas. Akan tetapi, dalam pengertian luas, penilaian dapat dilaksanakan pada awal suatu kegiatan (tes awal/ prates), selama kegiatan pembelajaran berlangsung (penilaian proses), dan bahkan, sebelum suatu kegiatan pembelajaran dikerjakan dapat dilaksanakan penilaian program secara internal.

Dari uraian di atas terlihat bahwa antara tujuan pembelajaran, bahan pembelajaran, kegiatan pembelajaran, alat bantu/media/sumber belajar, dan penilaian pembelajaran mempunyai hubungan yang erat. Keeratan hubungan itu tampak dengan jelas pada adanya hubungan antara tujuan pembelajaran dengan komponen yang lain, baik secara tersendiri maupun secara simultan. Adanya hubungan yang demikian erat menggambarkan bahwa komponen pengajaran sulit atau tidak dapat disiapkan sebelum komponen yang mendahuluinya ditetapkan.

Berdasarkan asumsi-asumsi di atas, maka dapat disimpulkan bahwa prinsip-prinsip dasar silabus pembelajaran bahasa Indonesia merupakan acuan dasar dalam memenej pembelajaran. Prinsip dasar ini harus memuat standar kompetensi, kompetensi dasar, indikator kompetensi, materi pembelajaran, strategi pembelajaran, dan evaluasi pembelajaran. 


\section{ANALISIS TERHADAP PRINSIP PROSES PEMBELAJARAN}

Proses pembelajaran bahasa Indonesia mengarahkan pebelajar untuk pengembangan keterampilan berbahasa yang menekankan pada kompetensi atau kemampuan dasar yang harus dimiliki oleh lulusan. Kompetensi tersebut merupakan kebulatan pengetahuan, sikap, dan keterampilan yang dapat didemonstrasikan dan ditunjukkan oleh pebelajar. Aspek lain yang tidak boleh diabaikan oleh para pelaku pendidikan adalah kecakapan hidup yang harus dimiliki pebelajar sebagai hasil dari pengalaman belajar. Agar pebelajar dapat mencapai kompetensi yang menjadi indikator keberhasilan, maka ada beberapa hal yang perlu diperhatikan lebih awal antara lain; kurikulum, silabus (perencanaan pembelajaran), pengorganisasian materi, pelaksanaan (kegiatan belajar mengajar), serta pendekatan dan metode yang diterapkan. ${ }^{12}$

Proses pembelajaran bahasa Indonesia merupakan aktualisasi dari segala sesuatu yang tertuang dalam rencana pembelajaran. Aktualisasi rencana pembelajaran merupakan titik kulminasi semua langkah untuk membantu pebelajar mengembangkan empat keterampilan berbahasa sehingga pebelajar dapat memiliki kemahiran berbahasa Indonesia. Agar kegiatan pembelajaran dapat membawa pebelajar ke arah kemahiran berbahasa Indonesia yang andal, maka hendaknya semua segmen pembelajaran diaflikasikan secara komunikatif dan integratif dalam kegiatan dimaksud.

Pembelajaran bahasa secara komunikatif adalah proses pembelajaran bahasa Indonesia yang mensinergikan unsur-unsur pembelajaran secara terpadu dan bahan ajar disajikan secara integratif dengan menjalin komunikasi multiarah dan multimakna. ${ }^{13}$

\section{Prinsip-prinsip Proses Pembelajaran Bahasa Indonesia}

Secara umum ada sejumlah prinsip proses pembelajaran bahasa Indonesia yang perlu diaplikasikan dalam kegiatan belajar mengajar, antara lain:

- Proses pembelajaran hendaknya mensinergikan seluruh komponen pembelajaran secara runtut;

- Senantiasa mendorong terwujudnya kemahiran berbahasa Indonesia yang andal pada diri peserta didik.

- Memberi kesempatan yang seluas-luasnya kepada pebelajar untuk mengambil bagian atau terlibat dalam tindak/peristiwa berbahasa dalam berbagai tindak tutur;

- Memberikan kepada pebelajar informasi, praktik, pelatihan, dan sejumlah pengalaman berbahasa yang sesuai dengan kebutuhannya, baik dalam kegiatan belajar mengajar maupun di luar kegiatan pembelajaran. 
- Sebaiknya pebelajar selalu mengoptimalkan penggunaan bahasa Indonesia secara aktual, baik di dalam maupun di luar proses pembelajaran;

- Senantiasa mengutamakan pengembangan keterampilan dan pembentukan kemahiran berbahasa, sedangkan pengetahuan kebahasaan dan sikap positif terhadap bahasa Indonesia dibina dan dikembangkan secara induktif;

- Memanfaatkan berbagai ragam bahasa Indonesia dalam tindak atau peristiwa berbahasa yang mungkin terjadi terutama ragam baku;

- Setiap aktivitas yang diciptakan dan dilaksanakan dalam pembelajaran bukan sekedar mengaktualisasikan metode/teknik pengajaran melainkan lebih dari itu mengembangkan kemahiran berbahasa bagi pebelajar;

- Memotivasi dan menyenangkan pebelajar dalam mengembangkan kemahiran berbahasa Indonesia dalam berbagai aktivitas sosial;

- Dapat mendorong munculnya performansi komunikatif yang andal secara terus-menerus. ${ }^{14}$

Proses pembelajaran dapat terlaksana dengan baik apabila unsurunsur pendidikan bersinergi secara aktif untuk membangun komunkasi multiarah, serta mensinergikan segmen-segmen kebahasan dalam proses pembelajaran.

\section{Prinsip KBM Bahasa Indonesia}

Pembelajaran bahasa Indonesia merupakan kegiatan yang bertujuan untuk mengembangkan empat keterampilan berbahasa bagi pebelajar, di sisi lain kegiatan pembelajaran bahasa Indonesia merupakan kegiatan bermakna karena kegiatan belajar seharusnya berarti dan berguna bagi pebelajar dalam kehidupan sehari-hari. Sementara itu, kegiatan mengajar (oleh pengajar) tentu tidak bisa dilepaskan dari kegiatan belajar mengajar. Kegiatan mengajar merupakan tindakan-tindakan pemula dan pemicu bagi terjadinya kegiatan dan peristiwa belajar. Oleh karena itu, kegiatan mengajar dan belajar tidak dapat dipisahkan satu dengan lainnya. Keduanya merupakan kegiatan yang direncanakan dan dilaksanakan secara terpadu dalam suatu paket yang utuh. Sebagai salah satu komponen pengajaran, kegiatan belajar-mengajar dipilih dan ditetapkan dengan memperhatikan indikator yang akan dicapai, karakteristik, bahan ajar, kemampuan awal pebelajar, dan pertimbangan metodologis lainnya.

\section{Prinsip-prinsip Pendekatan (Metode)}

Savignon dalam Ibrahim telah menyusun prinsip-prinsip pembelajaran bahasa Indonesia berdasarkan pendekatan komunikatif-integratif sebagai berikut: 
- Penggunaan bahasa bersifat komunikatif, yaitu peserta didik menerapkan pengetahuannya tentang sistem bahasa/kaidah-kaidah kebahasaan secara aplikatif dari bahasa target yang dipahami.

- Penerapan keterampilan berbahasa dalam berkomunikasi harus ditopang oleh tiga kemampuan, yaitu:

$\Rightarrow$ kemampuan menempatkan diri sebagai peserta tutur (partisipan tutur),

$\Rightarrow$ kemampuan mengantisipasi situasi tutur,

$\Rightarrow$ kemampuan memahami tujuan interaksi.

- Pembelajaran bahasa harus senantiasa didasarkan pada kebutuhan dan minat pebelajar. Oleh karena itu, sebelum menyusun silabus pembalajaran sebaiknya diadakan observasi terlebih dahulu untuk mengakomodasi kebutuhan dan minat pebelajar bahasa.

- Latihan menerapkan kaidah-kaidah bahasa disajikan secara kontekstual melalui teks atau wacana.

- Tenaga pengajar sebaiknya menempuh berbagai metode atau cara yang memungkinkan pebelajar aktif dalam berbagai tindak komunikasi daam kegiatan belajar mengajar. ${ }^{15}$

Pada sisi lain, Chastain dalam Tollah mengemukakan secara khusus prinsip-prinsip pendekatan komunikatif sebagai berikut:

- Pendekatan komunikatif mengarahkan untuk berupaya memiliki kemampuan yang sama atau hampir sama dengan kemampuan penutur asli terhadap bahasanya.

- Pendekatan komunikatif dalam pembelajaran bahasa mengarahkan tenaga pengajar untuk merancang dan menyajikan materi pembelajaran secara berkesinambungan.

- Tenaga pengajar dan materi pembelajaran serta proses belajar mengajar hendaknya memotivasi pebelajar untuk menggunakan bahasa target secara kreatif.

- Pembelajaran kebahasaan harus dijelaskan dan didiskusikan secara tuntas kemudian diterapkan dalam penggunaan bahasa secara nyata.

- Kegiatan belajar mengajar harus selalu bemakna. Pebelajar harus memahami materi pembelajaran. Oleh karena itu, dalam menyusun materi pembelajaran harus mempertimbangkan kebutuhan dan perkembangan kognitif peserta didik.

- Di samping itu, tenaga pengajar harus mencermati cara belajar pebelajar untuk dijadikan sebagai dasar pertimbangan dalam strategi belajar yang tepat. 16

Berdasarkan prinsip-prinsip pendekatan komunikatif, yang telah dideskripsikan tersebut di atas, dapat dipahami beberapa prinsip pembelajaran bahasa Indonesia secara komunikatif antara lain: 
- Pendekatan komunikatif menopang pebelajar agar terampil menggunakan bahasa dalam berkomunikasi.

- Materi pembelajaran (bahan ajar) disajikan dalam konteks, dengan asumsi bahwa bahasa senantiasa berkonteks.

- Pendekatan komunikatif memberi peluang yang besar terhadap pebelajar untuk berkreasi dalam mengembangkan materi pembelajaran.

- Pendekatan komunikatif memposisikan tenaga pengajar selaku fasilitator, pengarah, pembina, penasihat, dan semacamnya.

- Belajar bahasa adalah pembentukan kebiasaan yang mengarahkan pebelajar dapat menggunakan bahasa secara spontan.

- Pendekatan komunikatif tampaknya cenderung mengembangkan kompetensi komunikatif dan menanamkan kemampuan berkomunikasi dalam kegiatan belajar mengajar.

- Materi pembelajaran disusun berdasarkan minat dan kebutuhan pebelajar.

- Tujuan pembelajaran bahasa secara komunikatif adalah mengembangkan kompetensi agar pebelajar terampil menggunakan bahasa dalam berbagai tujuan dan peristiwa.

Dengan demikian, pembelajaran bahasa Indonesia dengan pendekatan komunikatif dan integratif tidak hanya menekankan segmen-segmen kebahasaan, tetapi sekaligus menekankan kemampuan berkomunikasi bagi pebelajar dalam situasi nyata dan dalam konteks komunikasi yang sebenarnya. Jadi, dalam pembelajaran bahasa Indonesia secara komunikatif dan integratif, bahasa diajarkan dengan cara mempraktikkan atau melatihkan berbagai aspek kebahasaan dalam berbagai bentuk kegiatan berdasarkan situasi dan komunikasi yang bermakna.

\section{PENUTUP}

Ada tiga prinsip yang perlu diperhatikan dalam pembelajaran bahasa Indonesia, yaitu:

Pertama, prinsip kebenaran, yaitu prinsip yang mengacu kepada kegramatikalan kalimat sesuai dengan kaidah-kaidah sintaksis yang berlaku. Gramatika suatu bahasa mesti berisi deskripsi mengenai kompetensi yang terdapat pada rana kognitif penutur dan lawan tutur. Kompetensi kebahasaan meliputi unsur-unsur bahasa seperti: bunyi, gramatika, makna, dan leksikon. Kompotensi gramatika meliputi kompotensi struktur kata (bentukan kata) dan kompetensi struktur kalimat (kompetensi bentukan kalimat).

Kedua, prinsip kecocokan, yaitu prinsip yang mengacu pada kecocokan dengan konteks penggunaan kalimat dalam berkomunikasi. Dengan 
kata lain, prinsip kecocokan memadukan antara makna kalimat dengan konteks komuikasi.

Ketiga, prinsip interaksi, yaitu prinsip yang mengarahkan terciptanya interaksi dalam kegiatan pembelajaran, baik interaksi antara tenaga pengajar dengan pebelajar, interaksi antara pebelajar dengan pebelajar, maupun interaksi antara pebelajar dengan lingkungan. Prinsip ini tidak lepas dari kompotensi komunikatif yang memungkinkan penutur mampu menggunakan bahasa sebagai alat komunikasi.

\section{CATATAN AKHIR:}

1. Lihat Widodo Hs., Pembelajaran Bahasa Indonesia: Pemberdayaan Potensi Diri Pembelajar Melalui Strategi Inovatif, Malang: Universitas Negeri Malang, t.th., $h$. 1-3.

2. Disadur dari Depdiknas, Kurikulum 2004 Mata Pelajaran Bahasa dan Sastra Indonesia, Jakarta: Depdiknas, 2004, h. 4.

3. Disadur dari Sudjatmiko dan Lili Nurlaili, Kurikulum Berbasi Kompetensi. Jakarta: Departemen Pendidikan Nasional, 2003, h. 7.

4. Departemen Pendidikan Nasional, Undang-undang Sisdiknas (Sistem Pendidikan Nasional) 2003 (UU RI No. 20 Th. 2003), cetakan I, Jakarta: Sinar Grafika, 2003, h. 5-6.

5. Disadur dari Sudjatmiko dan Lili Nurlaili, Kurikulum Berbasis Kompetensi, Jakarta: Departemen Pendidikan Nasional, 2003, h. 7-8.

6. Bandingkan Sudjatmiko dan Lili Nurlaili, Kurikulum Berbasis Kompetensi, Jakarta: Departemen Pendidikan Nasional, 2003, 24.

7. Disadur dari Sudjatmiko dan Lili Nurlaili, Kurikulum Berbasis Kompetensi, Jakarta: Departemen Pendidikan Nasional, 2003, h. 26-27.

8. Syahruddin Kaseng, Linguistik Terapan: Pengantar Menuju Pengajaran Bahasa yang Sukses, Jakarta: Departemen Pendidikan dan Kebudayaan Direktorat Jenderal Pendidikan Tinggi, 1989, h. 34-55.

9. M. Subana dan Sunarti, Strategi Belajar Mengajar Bahasa Indonesia Berbagai Pendekatan, Metode, Teknik, dan Media Pengajaran, Bandung, t.th., h. 287.

10. Azhar Arsyad, "Strategi Penggunaan Media Modern dalam Strategi Pembelajaran Pendidikan Agama dan Bahasa", Makalah, t.th., h. 4.

11. Lihat Sujatmiko dan Lili Nurlaili, Kurikulum Berbasis Kompetensi, Jakarta: Departemen Pendidikan Nasional, 2003, h. 28.

12. Winarno dan R. Eko Djuniarto, Perencanaan Pembelajaran, Jakarta: Direktur Pendidikan Dasar dan Menengah, 2003, h. 2.

13. Ibrahim, Pembelajaran Struktur Kalimat Bahasa Indonesia Secara Komunikatif, Makassar: Universitas Negeri Makassar, 2001, h. iv.

14. Lihat Suyono dan Mansur Muslich, Panduan Pengajaran Bahasa Indonesia, Malang: t.th., h. 98.

15. Ibrahim, Pembelajaran Struktur Kalimat Bahasa Indonesia Secara Komunikatif, Makassar: Program Pascasarjana UNM, 2001, h. 21-23.

16. Ahmad Tollah, Kajian Pendekatan Komunikatif dalam Pengajaran Bahasa Indonesia, Malang: PPs IKIP Malang, 1996, h. 21. 


\section{DAFTAR PUSTAKA:}

Arsyad, Azhar, "Strategi Penggunaan Media Modern dalam Strategi Pembelajaran Pendidikan Agama dan Bahasa", Makalah, t.th.

Departemen Pendidikan Nasional, Undang-undang Sisdiknas (Sistem Pendidikan Nasional) 2003 (UU RI No. 20 Th. 2003), cetakan I, Jakarta: Sinar Grafika, 2003.

Depdiknas, Kurikulum 2004 Mata Pelajaran Bahasa dan Sastra Indonesia, Jakarta: Depdiknas, 2004.

Ibrahim, Pembelajaran Struktur Bahasa Indonesia Secara Komunikatif, Makassar: Universitas Negeri Makassar, 2001.

Kaseng, Syahruddin, Linguistik Terapan: Pengantar Menuju Pengajaran Bahasa yang Sukses, Jakarta: Departemen Pendidikan dan Kebudayaan Direktorat Jenderal Pendidikan Tinggi, 1989.

Subana, M. dan Sunarti, Strategi Belajar Mengajar Bahasa Indonesia Berbagai Pendekatan, Metode, Teknik, dan Media Pengajaran, Bandung, t.th.

Sudjatmiko dan Lili Nurlaili, Kurikulum Berbasis Kompetensi. Jakarta: Departemen Pendidikan Nasional, 2003.

Suyono dan Mansur Muslich, Panduan Pengajaran Bahasa Indonesia, Malang: t.th.

Tollah, Ahmad, Kajian Pendekatan Komunikatif dalam Pengajaran Bahasa Indonesia, Malang: PPs IKIP Malang, 1996.

Widodo Hs., Pembelajaran Bahasa Indonesia: Pemberdayaan Potensi Diri Pembelajar Melalui Strategi Inovatif, Malang: Universitas Negeri Malang, t.th.

Winarno dan R. Eko Djuniarto, Perencanaan Pembelajaran, Jakarta: Direktur Pendidikan Dasar dan Menengah, 2003. 